The 9th International Symposium on Automation and Robotics in Construction June 3-5, 1992 Tokyo, Japan

\title{
Prospects for Applying Automation/Robotization of Life-Line Piping Construction Work
}

\author{
Kentaro Yoshida (TOKYO GAS CO., LTD.) \\ Yoshihiko Nojiri (AIREC ENGINEERING CORPORATION) \\ Construction Robotics Committee of Japan Society of Civil Engineers
}

\begin{abstract}
In this report, the present condition of life-line piping construction work has been analyzed. Life-line piping includes water supply, sewerage, electric power, city gas and communication and need of Automation and Robotization in construction work has also been studied. The group arranged the technical problems attended for automated construction system and proposed images of the system. The images are comprised with systems for advanced open cut method and trenchless piping method in which a vertical shaft is employed. This report includes the effects of the society accompany with automated construction system.
\end{abstract}

\section{INTRODUCTION}

Most of life-line services which indispensable to maintain city functions such as water supply, sewerage, electric power, city gas and communication are supplied by under ground pipelines or tunnels. Most of these life-lines are small scaled structures so it is likely that these facilities were mostly constructed by manpower. The ratio of construction done by machine is seemed low. This due to the small scaled work and spreaded site. Moreover in the city, it is not suitable for machine construction that existing utility lines are overcrowded and its locations are not always clear. The Committee, in which life-line concerned members are include has aimed the future and proposed new automated pipe-line construction systems. Though this report has not mentioned its detail, the Committee also studied issues such as organization images which will develop new systems, how to spread developed new system, and its effect to the society.

\section{PRESENT SITUATION OF AUTOMATED/ROBOT SYSTEM FOR PIPING CONSTRUCTION WORK}

Table 1 shows automated/robot system for small scaled familiar piping work. The technical level shown in the Table has been evaluated according to the following criterion.

A: The machine available sensor detected information and can make decision for next process.

B: Though the machine available sensor detected information, the decision for next step is done by operator.

C: The machine can not available sensor detected information and is operated by operator, this is only mechanization level or less.

In the Table, all items are resulted level $\mathrm{C}$. The present situation is only mechanized level and large part of the work depends on manpower. When compared with other construction work, the piping work is lagging in application of automated/robot system. 
Table 1 Work Items for Piping Construction Work and the Present Situation of Application of Automated/Robot System

\begin{tabular}{|c|c|c|c|c|}
\hline $\begin{array}{l}\text { Work } \\
\text { items }\end{array}$ & $\begin{array}{l}\text { Tech- } \\
\text { nical } \\
\text { level }\end{array}$ & Content of work & $\begin{array}{l}\text { Present } \\
\text { applica- } \\
\text { tion of } \\
\text { automated/ } \\
\text { robot sys- } \\
\text { tem }\end{array}$ & Problems \\
\hline $\begin{array}{l}\text { Setting of } \\
\text { barricade }\end{array}$ & $\mathrm{C}$ & $\begin{array}{l}\text { Bringing in and } \\
\text { setting of safety } \\
\text { equipment. }\end{array}$ & 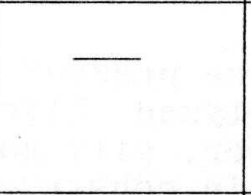 & $\begin{array}{l}\text { Car intrusion } \\
\text { Effect to the } \\
\text { traffic and stores } \\
\text { (ditto with fol- } \\
\text { ling column) }\end{array}$ \\
\hline $\begin{array}{l}\text { Pavement } \\
\text { breaking }\end{array}$ & $\mathrm{C}$ & $\begin{array}{l}\text { Cut and peel pave- } \\
\text { ment and load the } \\
\text { debris into truck. }\end{array}$ & - Breaker & $\begin{array}{l}\text { Noise, vibration } \\
\text { dust. } \\
\text { Hard work }\end{array}$ \\
\hline $\begin{array}{l}\text { Excavation, } \\
\text { sheathing }\end{array}$ & C & $\begin{array}{l}\text { Excavate ground to } \\
\text { the designed depth } \\
\text { without damaging } \\
\text { any existing } \\
\text { structures } \\
\text {. Setting sheathing. }\end{array}$ & $\begin{array}{l}\text { Trencher } \\
\text { Back-hoe } \\
\text { Crane } \\
\text { attached } \\
\text { truck }\end{array}$ & $\begin{array}{l}\text { Noise, vibration, } \\
\text { stain } \\
\text { Hard work } \\
\text {. Fupture of soil } \\
\text { Falling accident } \\
\text { Difficulty of soil } \\
\text { disposal } \\
\text { Give damages to } \\
\text { existing buried } \\
\text { structure }\end{array}$ \\
\hline Piping work & $\mathrm{C}$ & $\begin{array}{l}\text { Make level the } \\
\text { excavated trench } \\
\text { and connect pipe } \\
\text { to pre-installed } \\
\text { one. }\end{array}$ & $\begin{array}{l}\text { Joint } \\
\text { setter } \\
\text { (partial- } \\
\text { ly } \\
\text { applied) } \\
\text { Crane } \\
\text { attached } \\
\text { truck }\end{array}$ & $\begin{array}{l}\text { Hard work } \\
\text { Rupture of soil } \\
\text { Falling accident } \\
\text { Work is not effi- } \\
\text { cient. }\end{array}$ \\
\hline $\begin{array}{l}\text { Back- } \\
\text { filling, } \\
\text { removal of } \\
\text { sheathing }\end{array}$ & $\mathrm{C}$ & $\begin{array}{l}\text { Backfill sand } \\
\text { into trench and } \\
\text { tamp it without } \\
\text { giving damages to } \\
\text { installed pipes. } \\
\text { Fill sand to } \\
\text { indicated level } \\
\text { and tamp it. } \\
\text { Remove sheathing } \\
\text { and backfill. } \\
\end{array}$ & $\begin{array}{l}\text { Vibrat- } \\
\text { ing } \\
\text { compact- } \\
\text { or } \\
\text { Tamper } \\
\text { T Rammer } \\
\text { - Bearing } \\
\text { load } \\
\text { testing } \\
\text { machine }\end{array}$ & $\begin{array}{l}\text { Noise, vibration, } \\
\text { stain } \\
\text { Hard work } \\
\text { Rupture of soil } \\
\text { Work is not } \\
\text { efficient. }\end{array}$ \\
\hline $\begin{array}{l}\text { Restoration } \\
\text { of roadbed }\end{array}$ & $\overline{\mathrm{C}}$ & $\begin{array}{l}\text { Spread ballast and } \\
\text { tamp it. }\end{array}$ & & \\
\hline $\begin{array}{l}\text { Restoration } \\
\text { of pavement }\end{array}$ & $\mathrm{C}$ & $\begin{array}{l}\text { Provide temporary } \\
\text { pavement for } \\
\text { traffic. }\end{array}$ & $\begin{array}{l}\text { Roller } \\
\text { - Asphalt } \\
\text { sprayer }\end{array}$ & $\begin{array}{l}\text { Noise, vibration, } \\
\text { stain } \\
\text { Stink, get scalded } \\
\text { - Work accident } \\
\text { Control of mate- } \\
\text { rial temperature } \\
\end{array}$ \\
\hline $\begin{array}{l}\text { Removal of } \\
\text { barricade, } \\
\text { cleaning }\end{array}$ & $\mathrm{C}$ & $\begin{array}{l}\text { After removal of } \\
\text { safety equipment } \\
\text { and cleaning, the } \\
\text { traffic can be } \\
\text { opened. }\end{array}$ & - & $\begin{array}{l}\text { Accident of car } \\
\text { plunging into the } \\
\text { construction site }\end{array}$ \\
\hline
\end{tabular}




\section{PROPOSAL OF NEW AUTOMATED/ROBOT SYSTEM}

The proposal of new automated/robot system for life-line piping construction work is composed of following two systems.

(1) Automated/robot system for open cut piping work.

(2) Automated/robot system for trenchless (small diameter propulsion method) piping work.

3.1 Basic technical conditions of the system

Conditions to which the automated/robot system must be accorded are as follows.

(1) Functional conditions

* Grasp location of existing buried structures and do not give damage to these structures.

* Do not give unacceptable vibration and noise to the nearby environment.

* Take safety measures not only for workers but also for pedestrians and cars.

* Efficiency of the new system must be better than existing methods.

(2) Operational conditions

* The system must not requires expert operator.

(3) Conditions on standards

* A system must have multiple functions.

(4) Conditions of safety

* The system must have fail-safe mechanism which can prevent the machine from losing control.

3-2 Concrete study on the automated/robot system

(1) Automated/robot system for open cut method

It is assumed that the system is employed for one day restored lifeline piping construction work. The work included the process of from pavement breaking to pavement restoration and must be finished within one day. The dimension of the site is from 3 to $4 \mathrm{~m}$ wide and $50 \mathrm{~m}$ long. Table 2 shows the required functions for the robot for each work process. The images of the work robot are illustrated in Figure 1 Figure 4 . 
Table 2 Work Robot for Open cut Method and Its Function (1/2)

\begin{tabular}{|c|c|c|c|}
\hline \multirow{2}{*}{$\begin{array}{l}\text { Work } \\
\text { process }\end{array}$} & \multicolumn{2}{|r|}{ Functions of robot } & \multirow{2}{*}{$\begin{array}{l}\text { Name of } \\
\text { robot }\end{array}$} \\
\hline & Items & Details of function & \\
\hline \multirow[t]{3}{*}{$\begin{array}{l}\text { 1. Survey } \\
\text { before } \\
\text { commence- } \\
\text { ment of } \\
\text { work } \\
\text { (buried } \\
\text { structures } \\
\text { soil) }\end{array}$} & $\begin{array}{l}\text { (1) Memory } \\
\text { function } \\
\text { for infor- } \\
\text { mation of } \\
\text { existing } \\
\text { buried } \\
\text { structures }\end{array}$ & $\begin{array}{l}\text { Memorize existing buried struc- } \\
\text { tures record transmitted from } \\
\text { road management system within } \\
\text { for the construction span. }\end{array}$ & \multirow[t]{3}{*}{$\begin{array}{l}\text { Survey/ } \\
\text { design } \\
\text { robot } \\
\text { (Figure 1) }\end{array}$} \\
\hline & $\begin{array}{l}\text { (2) Survey- } \\
\text { ing func- } \\
\text { tion for } \\
\text { buried } \\
\text { structures } \\
\text { (Trenchless } \\
\text { method) } \\
\end{array}$ & $\begin{array}{l}\text { Using data transmitted from road } \\
\text { management system, survey buried } \\
\text { structures from road surface. }\end{array}$ & \\
\hline & $\begin{array}{l}\text { (3) Auto- } \\
\text { mated } \\
\text { design } \\
\text { function }\end{array}$ & $\begin{array}{l}\text { Prepare work drawings according } \\
\text { to data given by road manage- } \\
\text { ment system and result of site } \\
\text { survey } \\
\text { Transmit work drawings into } \\
\text { construction machine or robot }\end{array}$ & \\
\hline \multirow[t]{2}{*}{$\begin{array}{l}\text { 2. Pavement } \\
\text { breaking }\end{array}$} & $\begin{array}{l}\text { (1) Pavement } \\
\text { breaking } \\
\text { function }\end{array}$ & $\begin{array}{l}\text { - Recognizing its location and } \\
\text { according to drawings the robot } \\
\text { must cut asphalt layer along } \\
\text { instructed line. } \\
\text { Pavement block must be cut into } \\
\text { smaller block. }\end{array}$ & \multirow[t]{2}{*}{$\begin{array}{l}\text { Pavement } \\
\text { cutting and } \\
\text { breaking } \\
\text { robot } \\
\text { (Figure 2) }\end{array}$} \\
\hline & $\begin{array}{l}\text { (2) Small } \\
\text { block load- } \\
\text { ing func- } \\
\text { tion }\end{array}$ & $\begin{array}{l}\text { The robot loads small blocks } \\
\text { into transportation machine. }\end{array}$ & \\
\hline \multirow[t]{2}{*}{$\begin{array}{l}\text { 3xcava- } \\
\text { tion }\end{array}$} & $\begin{array}{l}\text { (1) Function } \\
\text { of excava- } \\
\text { tion and } \\
\text { soil } \\
\text { disposal }\end{array}$ & $\begin{array}{l}\text { - Recognizing its location and } \\
\text { according to drawings, the robot } \\
\text { must excavate ground avoiding } \\
\text { buried structure and haul the } \\
\text { soil out of trench. The image } \\
\text { of this work is not that using } \\
\text { machine and cutting natural } \\
\text { ground, but is soft image which } \\
\text { breaking soil using fluid mate- } \\
\text { rial and the soil is sucked out. }\end{array}$ & \multirow[t]{2}{*}{$\begin{array}{l}\text { Excavation, } \\
\text { sheathing, } \\
\text { pipe set- } \\
\text { ting, back- } \\
\text { fill robot } \\
\text { (Figure } 3 \text { ) }\end{array}$} \\
\hline & $\begin{array}{l}\text { (2) Function } \\
\text { of prevent } \\
\text { to damage } \\
\text { to buried } \\
\text { structures }\end{array}$ & $\begin{array}{l}\text { To prevent breaking unknown } \\
\text { buried structures, the tip of } \\
\text { cutting tool must be provided } \\
\text { buried structure sensor and } \\
\text { come to a immediate stop before } \\
\text { the structure damaged. }\end{array}$ & \\
\hline
\end{tabular}


Table 2 Work Robot for Open Cut Method and Its Function (2/2)

\begin{tabular}{|c|c|c|c|}
\hline \multirow{2}{*}{$\begin{array}{l}\text { Work } \\
\text { process }\end{array}$} & \multicolumn{2}{|r|}{ Functions of robot } & \multirow{2}{*}{$\begin{array}{l}\text { Name of } \\
\text { robot }\end{array}$} \\
\hline & Items & Details of function & \\
\hline 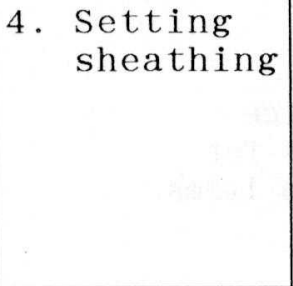 & $\begin{array}{l}\text { (1) Sheath- } \\
\text { ing setting } \\
\text { function }\end{array}$ & $\begin{array}{l}\text { According drawings the robot } \\
\text { must excavate ground avoiding } \\
\text { buried structures recognizing } \\
\text { its location and buried struc- } \\
\text { tures. Then to prevent ground } \\
\text { rupture, it will continuously } \\
\text { set sheathing. }\end{array}$ & $\begin{array}{l}\text { Excavation, } \\
\text { sheathing, } \\
\text { pipe set- } \\
\text { ting, back- } \\
\text { fill robot } \\
\text { (Figure } 3 \text { ) }\end{array}$ \\
\hline \multirow[t]{2}{*}{$\begin{array}{l}\text { 5. } \\
\text { set } \\
\text { piping }\end{array}$} & $\begin{array}{l}\text { (1) Piping } \\
\text { work } \\
\text { function }\end{array}$ & $\begin{array}{l}\text { Lay pipe for piping into the } \\
\text { trench avoiding buried struc- } \\
\text { tures and set pipe according to } \\
\text { indicated location. }\end{array}$ & \\
\hline & $\begin{array}{l}\text { (2) Pipe } \\
\text { connecting } \\
\text { function }\end{array}$ & $\begin{array}{l}\text { A pipe set into trench must be } \\
\text { connected with pre-installed } \\
\text { pipe. To avoid complicated work, } \\
\text { the joint must be simple } \\
\text { mechanism such as insert type. } \\
\text { Pipe holding arm must be devel- } \\
\text { oped which can avoid existing } \\
\text { structures. }\end{array}$ & \\
\hline \multirow[t]{3}{*}{$\begin{array}{l}\text { 6. Backfill } \\
\text { and tamp, } \\
\text { removal } \\
\text { of } \\
\text { sheathing }\end{array}$} & $\begin{array}{l}\text { (1) Backfill } \\
\text { function }\end{array}$ & $\begin{array}{l}\text { According to drawings and } \\
\text { avoiding buried structures the } \\
\text { robot must backfill the trench } \\
\text { with appropriate soil. }\end{array}$ & \\
\hline & $\begin{array}{l}\text { (2) Tamping } \\
\text { function }\end{array}$ & $\begin{array}{l}\text { Tamp the backfilled soil as } \\
\text { hard as the natural ground. }\end{array}$ & \\
\hline & $\begin{array}{l}\text { (3) Work } \\
\text { control } \\
\text { function }\end{array}$ & $\begin{array}{l}\text { During the tamping, check the } \\
\text { bearing capacity of backfilled } \\
\text { soil and roadbed and record the } \\
\text { data. }\end{array}$ & \\
\hline $\begin{array}{l}\text { 7. Restora- } \\
\text { tion of } \\
\text { roadbed }\end{array}$ & $\begin{array}{l}\text { (1) Paving } \\
\text { function }\end{array}$ & $\begin{array}{l}\text { According to drawings and } \\
\text { recognizing its location the } \\
\text { robot will be restoring pavement } \\
\text { along designed line. }\end{array}$ & $\begin{array}{l}\text { Pavement } \\
\text { restoring } \\
\text { robot } \\
(\text { Figure } 4)\end{array}$ \\
\hline
\end{tabular}




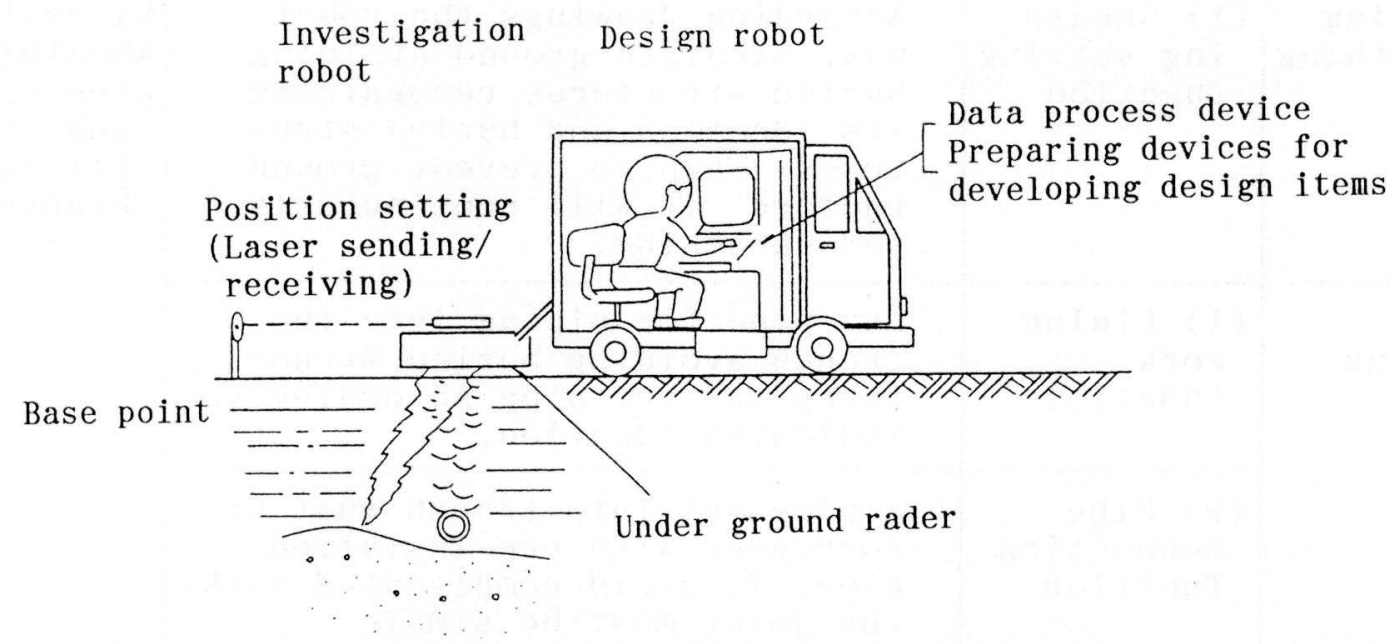

Figure 1 Survey/Design Robot

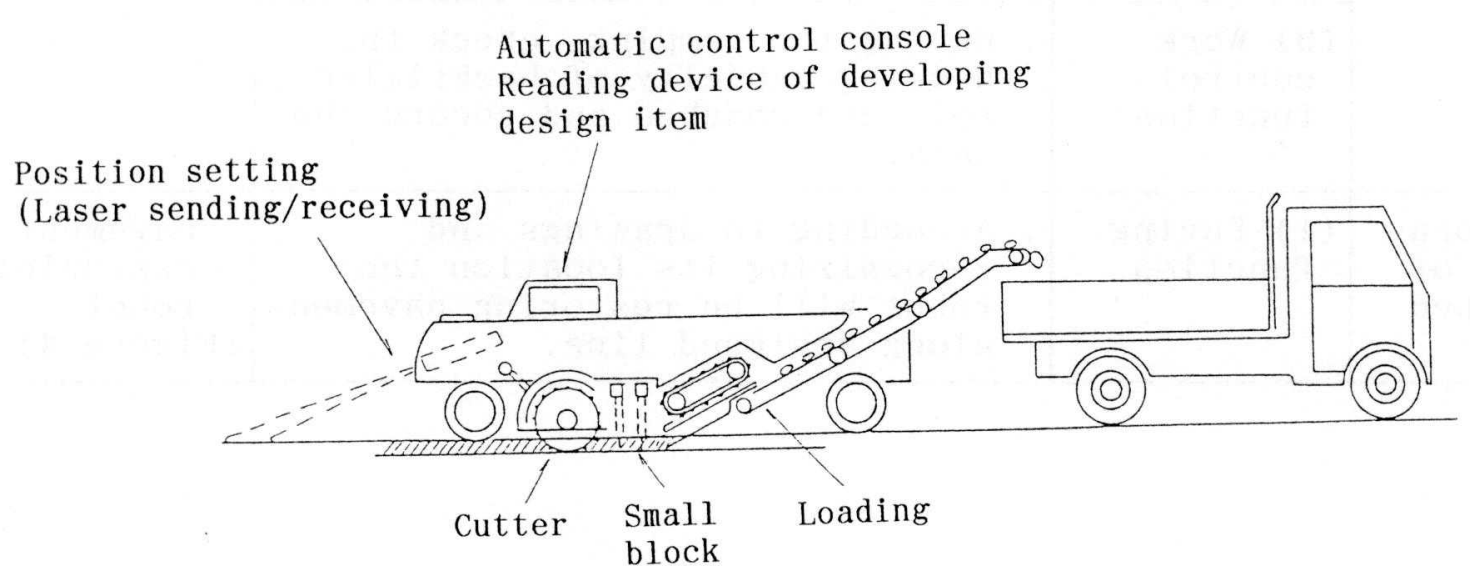

Figure 2 Pavement Cutting and Breaking Robot 


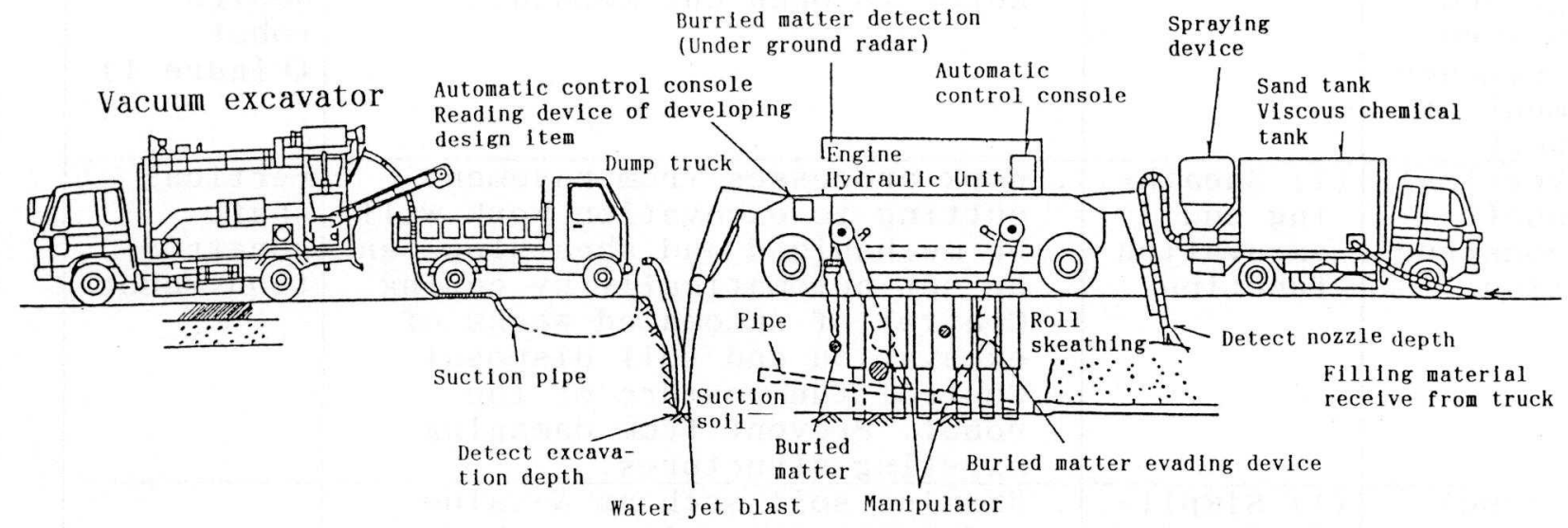

Figure 3 Excavation, Sheathing, Pipe Setting Backfill Robot

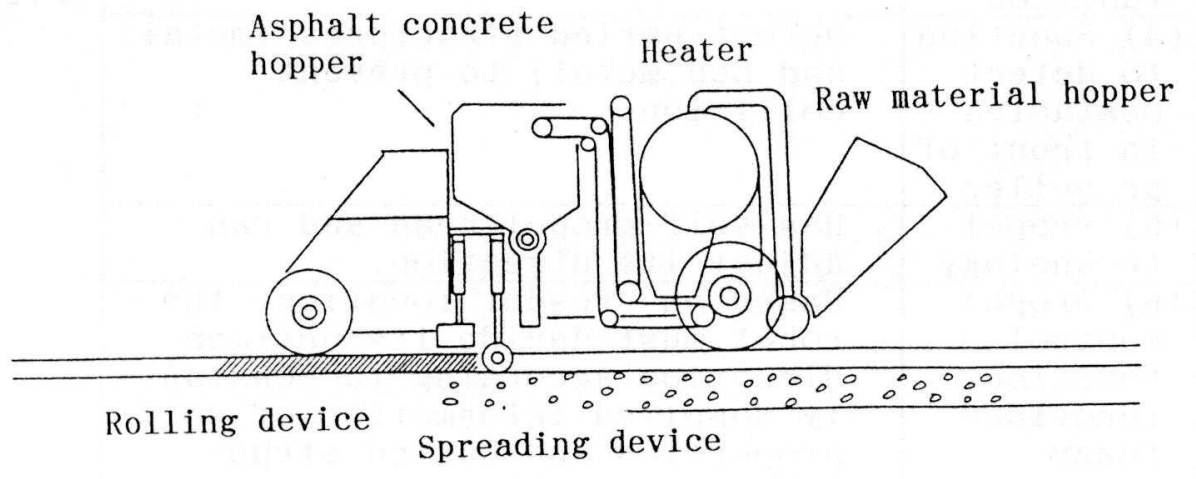

Figure 4 Pavement Restoring Robot

\section{(2) Automated/robot system for trenchless piping work}

In trenchless piping work, open cutting work is limited for vertical shaft only, and the system can be controlled by unified operation at the vertical shaft location, so this method may be the most suitable method for automated/robot system.

In this study, small diameter (less than $300 \mathrm{~mm}$ ) piping work, which is usually applied for a large part of life-line piping work, is considered. Table 3 shows the work process and corresponding robot function. Figure 5,6 show images of robot which will send out propeller from ground surface, this system required no vertical shaft. 
Table 3 Working Robot and Its Functions for Trenchless Method

\begin{tabular}{|c|c|c|c|c|}
\hline \multirow{2}{*}{\multicolumn{2}{|c|}{$\begin{array}{l}\text { Work } \\
\text { process }\end{array}$}} & \multicolumn{2}{|r|}{ Functions of robot } & \multirow{2}{*}{$\begin{array}{l}\text { Name of } \\
\text { robot }\end{array}$} \\
\hline & & Items & Details of function & \\
\hline & $\begin{array}{l}\text { Survey } \\
\text { ground } \\
\text { before } \\
\text { commence- } \\
\text { ment of } \\
\text { work }\end{array}$ & & Refer to Open Cut Method. & $\begin{array}{l}\text { Survey/ } \\
\text { design } \\
\text { robot } \\
\text { (Figure 1) }\end{array}$ \\
\hline & $\begin{array}{l}\text { Vertical } \\
\text { shaft } \\
\text { construc- } \\
\text { tion }\end{array}$ & $\begin{array}{l}\text { (1) Sheath- } \\
\text { ing and } \\
\text { excavation } \\
\text { function }\end{array}$ & $\begin{array}{l}\text { Work processes from pavement } \\
\text { cutting to excavation work will } \\
\text { be mechanized and sheathing can } \\
\text { be set automatically by casing. } \\
\text { Control of automated works of } \\
\text { excavation and soil disposal. } \\
\text { Control the posture of the } \\
\text { robot. Prevent from damaging } \\
\text { existing structures. }\end{array}$ & $\begin{array}{l}\text { Vertical } \\
\text { shaft } \\
\text { construc- } \\
\text { tion robot }\end{array}$ \\
\hline & \multirow[t]{7}{*}{ Propel } & $\begin{array}{l}\text { (1) Simpli- } \\
\text { fied soil } \\
\text { survey } \\
\text { function }\end{array}$ & $\begin{array}{l}\text { Examine soil such as N-value } \\
\text { and soil properties which are } \\
\text { needed for setting work condi- } \\
\text { tions using bore hole. }\end{array}$ & \multirow{7}{*}{$\begin{array}{l}\text { Propel } \\
\text { robot } \\
\text { (Figure 5) }\end{array}$} \\
\hline & & $\begin{array}{l}\text { (2) Function } \\
\text { of setting } \\
\text { locations } \\
\text { for propel }\end{array}$ & $\begin{array}{l}\text { Make a total coordinates and } \\
\text { put in covering and off set } \\
\text { data then set location for } \\
\text { propel. }\end{array}$ & \\
\hline & & $\begin{array}{l}\text { (3) Location } \\
\text { survey } \\
\text { function }\end{array}$ & $\begin{array}{l}\text { Grasp propeller location cor- } \\
\text { rectly from road surface. }\end{array}$ & \\
\hline & & $\begin{array}{l}\text { (4) Function } \\
\text { to detect } \\
\text { obstacles } \\
\text { in front of } \\
\text { propeller }\end{array}$ & $\begin{array}{l}\text { Detect buried structures (metal } \\
\text { and non metal) to prevent } \\
\text { collision. }\end{array}$ & \\
\hline & & $\begin{array}{l}\text { (5) Propel } \\
\text { technology }\end{array}$ & $\begin{array}{l}\text { Has self-propel head and can } \\
\text { adjust its direction. }\end{array}$ & \\
\hline & & $\begin{array}{l}\text { (6) Propel } \\
\text { control } \\
\text { function } \\
\text { (provided } \\
\text { fuzzy } \\
\text { function) }\end{array}$ & $\begin{array}{l}\text { Based on present location, the } \\
\text { robot must decide its optimum } \\
\text { direction according to constant- } \\
\text { ly supplied information of soil } \\
\text { properties and buried struc- } \\
\text { tures. }\end{array}$ & \\
\hline & & $\begin{array}{l}\text { (7) Signal } \\
\text { transmit- } \\
\text { ting } \\
\text { function } \\
\end{array}$ & $\begin{array}{l}\text { Transmit information supplied } \\
\text { by propelier and detected } \\
\text { location from road surface to } \\
\text { the operation. }\end{array}$ & \\
\hline \multirow{3}{*}{\multicolumn{2}{|c|}{$\begin{array}{l}\text { 4. Piping } \\
\text { work }\end{array}$}} & $\begin{array}{l}\text { (1) Flexible } \\
\text { pipe }\end{array}$ & - Can be applied for curve piping. & \multirow{3}{*}{$\begin{array}{l}\text { Piping } \\
\text { robot for } \\
\text { propel } \\
\text { method } \\
\text { (Figure } 6 \text { ) }\end{array}$} \\
\hline & & $\begin{array}{l}\text { (2) Cast } \\
\text { in place } \\
\text { piping } \\
\text { technology }\end{array}$ & $\begin{array}{l}\text { Cast in place piping which can } \\
\text { applied for any curving piping } \\
\text { work. }\end{array}$ & \\
\hline & & $\begin{array}{l}\text { (3) Func- } \\
\text { tions of } \\
\text { automated } \\
\text { pipe joint } \\
\text { and setting } \\
\text { work }\end{array}$ & $\begin{array}{l}\text { Pipes are automatically bring } \\
\text { into shaft and connected except } \\
\text { (1), (2) mentioned pipes. }\end{array}$ & \\
\hline & $\begin{array}{l}\text { Restore } \\
\text { vertical } \\
\text { shaft }\end{array}$ & & Refer to Open Cut Method. & $\begin{array}{l}\text { Pavement } \\
\text { restoring } \\
\text { robot } \\
\text { (Figure 4) }\end{array}$ \\
\hline
\end{tabular}




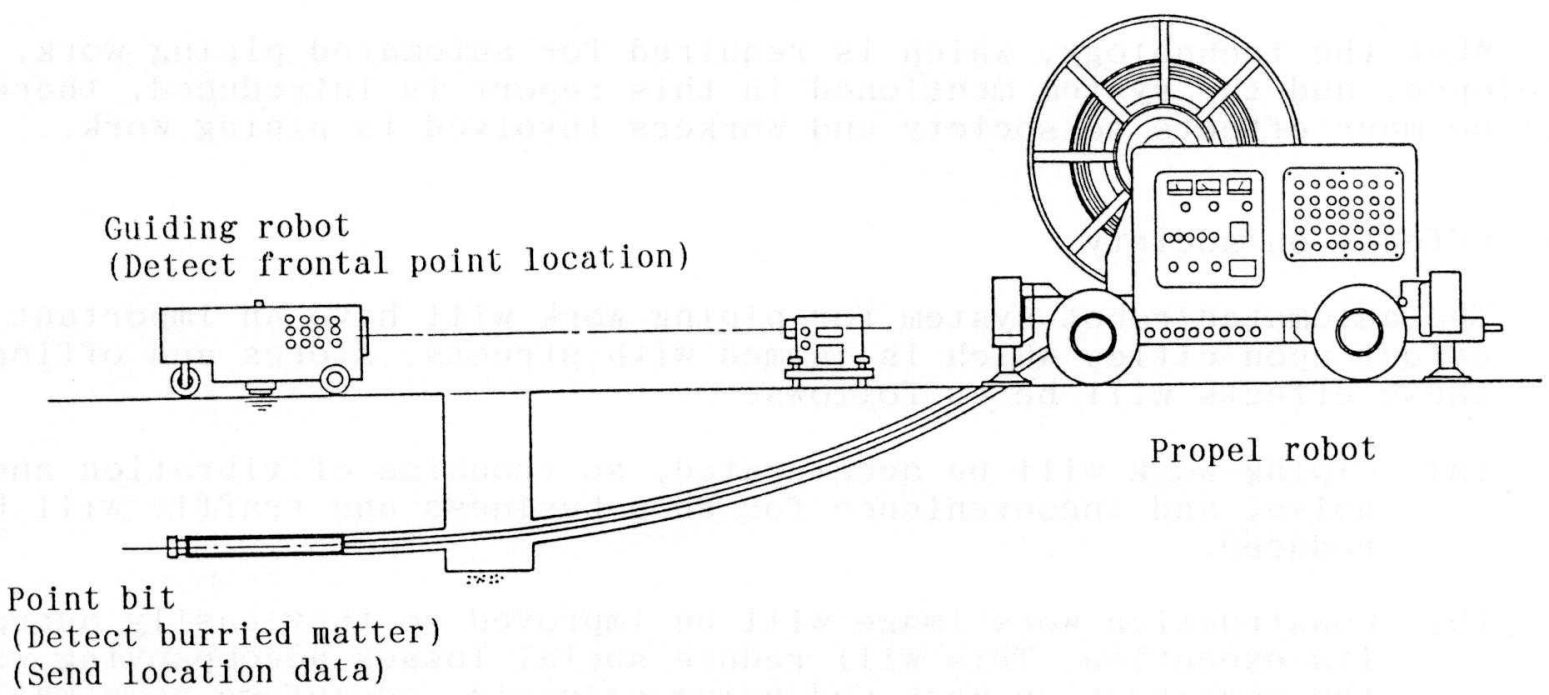

Figure 5 Propel Robot

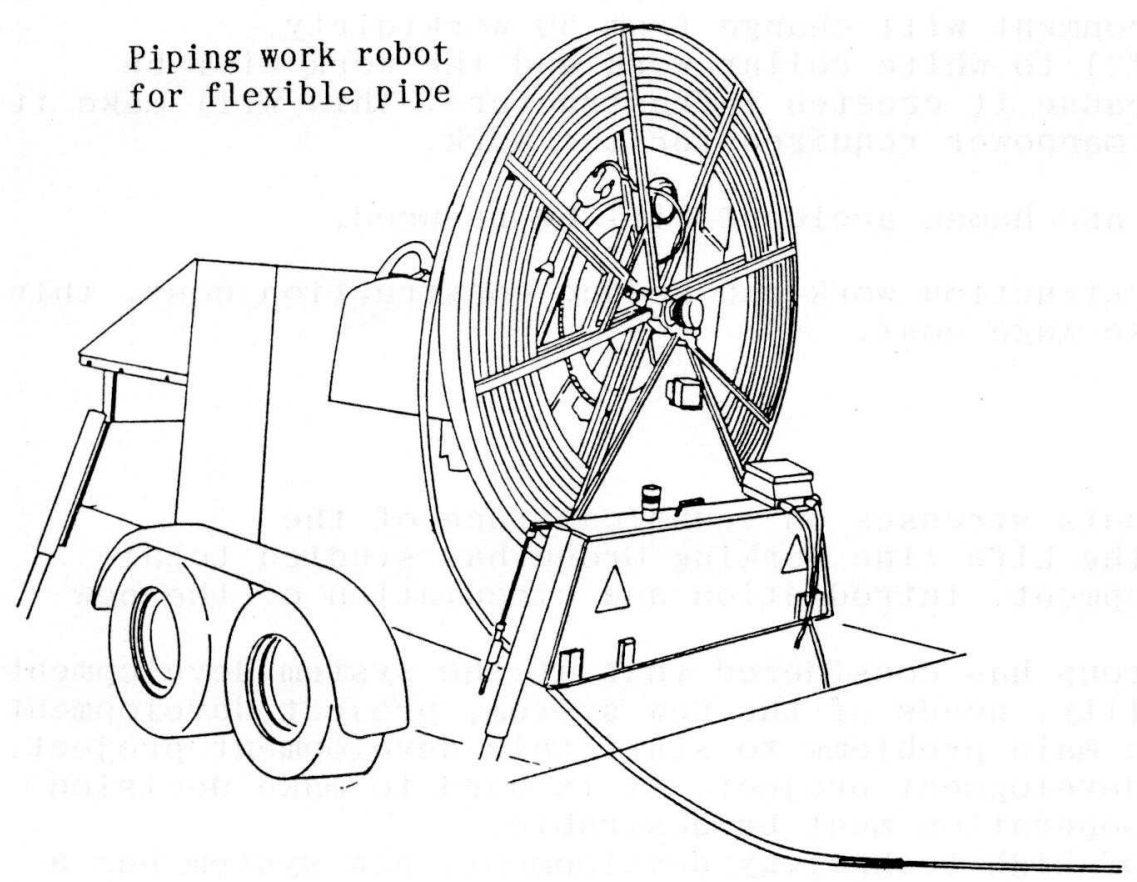

Piping work robot for regular pipe connecting

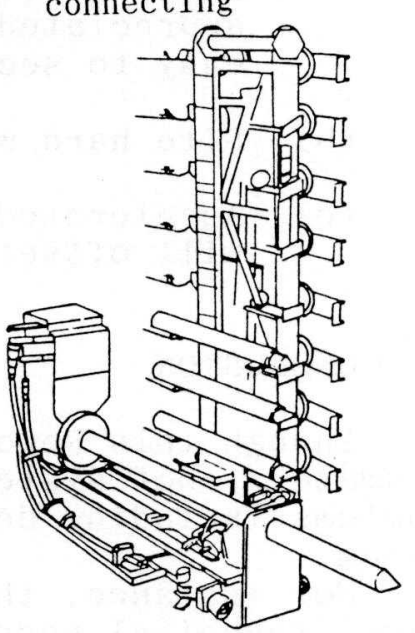

Figure 6 Piping Robot for Propel Method (flexible pipe and standard size pipe) 


\section{THE EFFECT OF INTRODUCING AUTOMATED/ROBOT TECHNOLOGY}

When the technology, which is required for automated piping work, is developed, and the system mentioned in this report is introduced, there will be many effects to society and workers involved in piping work.

\section{(1) Effects on society}

The automated/robot system for piping work will have an important effect upon cities which is jammed with streets, stores and offices, these effects will be as follows.

(a) Piping work will be accelerated, so troubles of vibration and noise, and inconvenience for shop business and traffic will be reduced.

(b) Construction work image will be improved so they easily accept its execution. This will reduce social losses accompanying with the construction work and bring economic advantage as a whole.

(c) Accelerated construction work will achieve economical construction then costs for infrastructure can be reduced.

(2) Effects upon piping work concerned person

The automated/robot system for piping work will have following effects upon owners, contractors and workers.

(a) Site work environment will change from 3D work(dirty, danger,difficult) to white collar work and the work will be appreciated because it creates infrastructure. This will make it easy to secure manpower required for the work.

(b) Site hard work and human accident will be reduced.

(c) Accelerated construction work can reduce construction cost, this will offset rose wage cost.

\section{CONCLUSION}

Though this Report puts stresses on technical face of the automated/robot system, the Life-line Working Group has studied total problems including development, introduction and circulation of the new system.

For instance, the Group has considered that at the system development stage, technical possibility, needs of the new system, project development cost and cost balance are main problems to start this development project, but for high technology development project, it is hard to make decision for single enterprise. Cooperation must be desirable.

At the first stage of high technology development, new system has a disadvantage of high cost than existing systems. We must view and accept this disadvantage at technological development standpoint, but if the period when the first cost can be recovered is unknown, it is hard to make the decision. The Working Group will appreciate if its activity can be any help for future high technology development. 